\title{
ЗАВІДОМО НЕЗАКОННІ ЗАТРИМАННЯ, ПРИВОДИ, ДОМАШНІ АРЕШТИ АБО ТРИМАННЯ ПІД ВАРТОЮ: ПИТАННЯ КРИМІНАЛЬНО-ПРАВОВОГО ХАРАКТЕРУ
}

Воронцов А. В.

Статтю присвячено наявним проблемам у кримінально-правовій характеристиці кваліфікуючих ознак злочину проти правосуддя, передбаченого $\mathrm{cm} .371$ КК, який вчиняється уповноваженими службовими особами досудового розслідування в прочесі здійснення правосуддя, та на їх підставі наданню шляхів вдосконалення чинного кримінального законодавства.

Кваліфікуючі ознаки вчинення завідомо незаконного затримання, приводу, домашнього арешту або тримання під вартою, передбачені ч. $3 \mathrm{~cm} .371 \mathrm{KK}$, мають чітко виражений і встановлений характер. Однак виникає ще одне актуальне питання щодо врахування у ч. $3 \mathrm{~cm} .371 \mathrm{KK}$ спричинення інших наслідків злочином (особливо тяжких). Обґрунтування такої позиції у відповідній частині статmі детальніше простежується через призму кваліфікованих ознак притягнення завідомо невинного до кримінальної відповідальності.

Тяжкі або особливо тяжкі наслідки, що можуть настати внаслідок завідомо незаконного затримання, приводу, домашнього арешту або тримання під вартою, а також внаслідок притягнення як обвинуваченого завідомо невинного, примушування давати показання, можна поділити на матеріальні і нематеріальні.

Завідомо незаконні затримання, приводи, домашні арешти або тримання під вартою повинні не тільки передувати настанню тяжких наслідків за часом, але й мають виступати головними і визначальними умовами необхідності тягти настання тяжких наслідків.

Зазначено, що слід підвищити межі заподіяння шкоди й врахувати заподіяння особливо тяжкої шкоди. Необхідність урахування в диспозиції статmі настання таких наслідків викликана низкою негативних тенденцій, які простежуються сьогодні в підрозділах правоохоронних органів, та дозволить розширити настання й інших негативних наслідків злочину, які на практиці не враховуються (розірвання контрактів, банкрутство, настання фінансової неспроможності тощо потрібно вважати тяжкими наслідками, а заподіяння тяжких тілесних ушкоджень, що спричинили смерть потерпілого, доведення до самогубства, заподіяння смерті тощо - особливо тяжкими). Отже, додаткова кваліфікація за сукупністю злочинів $\epsilon$ недоцільною.

Ключові слова: правосуддя, кваліфікуючі ознаки затримання, приводу, домашнього арешту, тримання під вартою, тяжкі наслідки, корисливий мотив, інші особисті інтереси, суб'єкти здійснення правосуддя, процесуальна діяльність, тлумачення.

Статья посвящена существующим проблемам в уголовно-правовой характеристике квалифицирующих признаков преступления против правосудия, предусмотренного $\mathrm{cm}$. 371 УК, которое совершается уполномоченными должностными лицами досудебного расследования в процессе осуществления правосудия, и на их основании предоставлению

Воронцов А. В., 2019 путей совершенствования действующего уголовного законодательства.

Квалифицирующие признаки совершения заведомо незаконных задержаний, приводов, домашних арестов или содержаний под стражей, предусмотренных ч. $3 \mathrm{~cm} .371$ УК, имеют четко выраженный и установленный характер. Однако возникает еще и актуальный вопрос об учете в ч. $3 \mathrm{~cm}$. 371 УК причинения иных последствий преступлением (особо тяжких). Обоснование такой позиции подробнее прослеживается через призму квалифицированных признаков привлечения заведомо невиновного к уголовной ответственности.

Указано, что следует повысить пределы причинения вреда и учесть причинение особо тяжкого вреда. Необходимость учета в диспозиции статьи наступления таких последствий вызвана рядом негативных тенденций, которые наблюдаются сегодня в подразделениях правоохранительных органов, и позволит расширить наступление других негативных последствий преступления, которые на практике не учитываются (расторжение контрактов, банкротство, наступление финансовой несостоятельности и т.д. нужно считать тяжкими последствиями, а причинение тяжких телесных повреждений, повлекшее смерть потерпевшего, доведение до самоубийства, причинение смерти и т.д. - особо тяжкими последствиями). Дополнительная квалификация по совокупности преступлений является нецелесообразной.

Ключевые слова: правосудие, квалифицирующие признаки задержания, привода, домашнего ареста, содержания под стражей, тяжкие последствия, корыстный мотив, иные личные интересы, субъекты правосудия, процессуальная деятельность, толкование.

The article is devoted to the existing problems in the criminal law characterization of qualifying signs of a crime against justice, provided for by Art. 371 of the Criminal Code, which is carried out by authorized officials of the pre-trial investigation in the process of administering justice and on their basis the provision of ways to improve the existing criminal law.

Qualifying signs of knowingly unlawful detention, drive, house arrest or detention under Part 3 of Art. 371 of the Criminal Code are clearly expressed and established. However, along with a certain one, another urgent question arises about accounting in part 3 of art. 371 of the Criminal Code causing other consequences of a crime (especially grave). The rationale for such an increase in the relevant part of the article can be traced in more detail through the prism of qualified signs of bringing a knowingly innocent person to criminal responsibility.

It is indicated that the limits of harm should be increased and the infliction of particularly serious harm should be taken into account in this part of the article. The need to take into account in the disposition of the article the occurrence of such consequences is caused by a number of negative trends that are observed today in law enforcement departments, and will expand the onset of other negative consequences of the crime, which are not taken into account in practice (termination of con- 
tracts, bankruptcy, financial insolvency, etc. - be considered serious, and causing serious bodily harm that resulted in the death of the victim, bringing to suicide, causing death, etc. - as especially $t$ mild consequences). Accordingly, additional qualification in the aggregate of crimes is inappropriate.

Key words: justice, qualifying signs of detention, drive, house arrest, detention, grave consequences, selfish motive, other personal interests, subjects of justice, procedural activity, interpretation.

Постановка проблеми та її актуальність. Ст. $26 \mathrm{Koн-}$ ституції України проголошує: «Кожна людина має право на свободу та особисту недоторканність. Ніхто не може бути заарештований або триматися під вартою інакше як за мотивованим рішенням суду і тільки в порядку та на підставах, встановлених законом<...>». На цьому шляху законодавче забезпечення кримінальної відповідальності за завідомо незаконні затримання, приводи, домашні арешти або тримання під вартою має важливе значення. Спеціальною правовою гарантією недоторканності особи $є$ встановлення кримінальним законодавством (у розд. XVIII ОЧ КК України «Злочини проти правосуддя») відповідальності спеціально уповноважених службових осіб за ст. 371 КК. Тільки у такому разі завдання, які стоять перед правосуддям, тобто захист прав і свобод людини та громадянина, стають спеціальним об'єктом кримінально-правової охорони у державі. Неправомірне ж (злочинне) застосування запобіжних та інших заходів не створює необхідних умов для досягнення мети, яка стоїть перед ним, та дискредитує органи, які його здійснюють [8; 10, с. 6].

Аналіз останніх досліджень і публікацій. У юридичній літературі зазначається, що кваліфікуючими ознаками у ч. 3 ст. 371 КК України («Спричинення тяжких наслідків») слід вважати:

1) самогубство та спробу вчинити самогубство. Дії підготовчого характеру, висловлювання наміру вчинити самогубство поняттям «спроба вчинити самогубство» не охоплюються. Це також загибель важкохворих близьких, які залишилися без нагляду, позбавлення життя такої особи іншими затриманими чи заарештованими [7, с. 1004-1008];

2) спричинення (заподіяння) шкоди здоров'ю. Це передбачені КК України тілесні ушкодження різного ступеня тяжкості (ст. ст. 121, 122, 125 КК) [2, с. 49-54; 6, с. 121].

Питання про те, чи були певні дії мученням або мордуванням, вирішує не судово-медична експертиза, а досудове слідство і суд (слідчий суддя).

Відносячи той чи інший злочин до певної групи, необхідно враховувати, що головним критерієм має бути мотив (мотиви) вчинення злочину. Отже, як кваліфікуюча ознака потребує конкретизації мотив вчинення завідомо незаконного затримання, приводу, домашнього арешту або тримання під вартою.

Мета статті - визначити кримінально-правовий характер завідомо незаконних дій щодо затримання, приводу, домашнього арешту або тримання під вартою.

Виклад основного матеріалу. Ні в психологічній, ні в юридичній літературі остаточно не сформульоване загальновизнане поняття як мотиву людської поведінки або діяльності, так і поняття мотиву злочину. 3 огляду на це мотивом злочину $\epsilon$ інтегральне психічне утворення, яке штовхає особу до вчинення суспільно небезпечного діяння та $€$ його підставою.
Сучасна доктрина кримінального права вбачає у мотиві спонукання до вчинення злочину, усвідомлене спонукання особи, яке викликало у неї рішучість вчинення злочину. Мотив вивчається як одна з ознак суб'єктивної сторони (складу злочину) завідомо незаконного затримання, приводу, домашнього арешту або тримання під вартою.

Під час визначення кримінально-правового змісту зазначеного злочину найчастіше підкреслюється, що мотив $\epsilon$ факультативною, тобто необов'язковою, другорядною ознакою суб'єктивної сторони злочину (ч. 1 або 2 ст. 371 КК України).

Проте не можна назвати завідомо незаконне затримання, привід, домашній арешт або тримання під вартою суспільно небезпечними діяннями, які не отримали свого процесуального обґрунтування, в яких не були визначені й доведені мотиви. За таких умов виникає необхідність встановлення всієї суб'єктивної сторони складу злочину, при цьому вина і мотив виступають безпосередніми обставинами, що підлягають доказуванню. Іншими словами, якщо не встановлено вину й мотив, то немає доказів вчинення особою злочинного діяння, яке містить склад злочину, передбаченого ч. 3 ст. 371 КК [4, ст. 91-94; 5].

У психологічному регулюванні будь-якої поведінки, а також злочину беруть участь не тільки усвідомлені, але й неусвідомлені компоненти. Мотиви, хоча окремі з них дуже часто не усвідомлюються, невід'ємні від свідомості в цілому, тобто відображають особистість, iї спрямованість, моральний образ. Неусвідомленість мотивів, у тому числі в осіб із психічними аномаліями, аніскільки не звільняє від кримінальної відповідальності за вчинення злочинних дій, оскільки суб'єкт може і не усвідомлювати їх рушійних стимулів, але усвідомлює їх кримінальний характер.

У ч. 3 ст. 371 КК мотив, як зазначалось, має різноманітний характер. Як влучно зауважував Б. Волков, «характер мотивів і зв'язок їх з метою, дією чи бездіяльністю - це основне в психологічному змісті службового злочину, що значною мірою визначає оцінку цих діянь та їхню суспільну небезпеку. Наприклад, можна бути поблажливим до незграбності, недосвідченості службової особи, але не можна прощати нечесності, жорстокості, кар'єризму й інших пороків, що посилюють службові злочини».

Корисливі мотиви - це прагнення винного одержати для себе вигоду в тій чи іншій формі, в тому чи іншому вигляді або отримати вигоду в інтересах третіх осіб. Вони $є$ одними із найпотужніших рушіїв людських дій. Вони знаходять свою підставу у інстинкті самозбереження, який стоїть на варті забезпечення організму матеріальними благами. Якщо відняти в людини закладені в ній в цьому напрямі прагнення, то втратиться сенс життя. Цей інстинкт $є$ не тільки інстинктом для таких дій, які підказуються інтересами егоїзму, але й живить нездорове i надмірне прагнення до матеріальних благ, що дозволяє говорити про корисливість.

Корисливий мотив криміналісти визначають як прагнення отримати яку-небудь матеріальну користь, вигоду, а також як спонуку, що виражає прагнення винного до нетрудової майнової вигоди. Обидва визначення випливають з етимологічного значення слова «користь», під якою розуміється вигода, зокрема і матеріальна користь. Проте таке визначення корисливого 
мотиву $\epsilon$ вузьким і не враховує того, що корисливий мотив не завжди пов'язаний з особистою матеріальною вигодою. Його не можна розглядати як просто прагнення до якої-небудь майнової чи матеріальної вигоди.

Болгарські кримінологи відзначають, що «вигода <...> буває і не чисто матеріальною, а супроводжується службовими амбіціями, міркуваннями особистого престижу». Такий підхід відповідає психологічній концепції мотиву, яка доводилася [9, с. 59-60].

Корисливість у завідомо незаконному затриманні, приводі, домашньому арешті або триманні під вартою визнається як прагнення особи до отримання матеріальної (майнової) вигоди без витрат власної суспільно корисної праці (заволодіти грошима, коштовностями, цінними паперами, майном, одержати майнові права, уникнути матеріальних витрат чи обов' язків або досягти іншої матеріальної вигоди).

Вчиняючи злочин, слідчий, діючи 3 корисливих мотивів, прагне отримати матеріальну вигоду за рахунок використання наданих йому відповідно до служби прав та повноважень. Завідомо незаконне тримання під вартою, поєднане з притягненням завідомо невинного до кримінальної відповідальності з корисливих мотивів (наприклад, внаслідок одержання неправомірної вигоди), значно підвищує ступінь суспільної небезпеки цих злочинів [2, с. $35 ; 7$, с. 1004].

Під іншими особистими інтересами (мотивами) слід розуміти кар'єризм, протекціонізм, конформізм, ревнощі, сімейність, помсту, заздрість, ненависть, бажання прикрасити стан речей (проваджень), отримати взаємну послугу, заручитися підтримкою у вирішенні будь-якого питання, приховати свою некомпетентність тощо [1, с. 149-150].

Одним із мотивів вчинення цих злочинів може бути й помста. Бажання помсти виникає на тлі суперечливих, неприязних стосунків між людьми. Її основа - життєва образа, незадоволення діями або вчинками іншої людини і бажання одержати задоволення від образи. Помста як мотив вчинення злочину передбачає прагнення одержати задоволення за заподіяне в минулому зло, дії, які істотно зачіпають інтереси винної особи або іiі близьких.

Заздрість і ненависть мають велику схожість із помстою. Як і помста, заздрість також характеризується непомірним егоїзмом, що може заподіяти шкоду іншій особі. Однак заздрість не пов'язана з якимись конкретними діями потерпілого, що обмежують права й свободи людини і громадянина, тобто з образливими діями. Заздрість - це виняткове породження індивідуальних морально-психологічних властивостей внутрішнього хворобливого стану самолюбства, що має поглиблений і прихований характер. Це зумовлює специфіку вчинення аналізованих злочинів на цьому підґрунті. Що стосується ненависті, то вона виражається у почутті ворожнечі до іншої особи. Така ворожнеча $є$ причиною вчинення злочину і стає його мотивом. Саме ж виникнення ненависті не завжди пов'язане з якимись конкретними діями потерпілого.

Конформістські погляди полягають у небажанні індивіда виділятися й ставати предметом підвищеної уваги, адже існує прагнення бути таким, як усі, страх змін, небажання проявляти ініціативу.

Отже, кваліфікуючі ознаки вчинення завідомо незаконних дій щодо затримання, приводу, домаш- нього арешту або тримання під вартою, передбачених ч. 3 ст. 371 КК, мають чітко виражений і встановлений характер. Однак виникає актуальне питання щодо врахування у ч. 3 ст. 371 КК спричинення інших наслідків злочином (особливо тяжких). Обґрунтування такої позиції у відповідній частині статті детальніше простежується через призму кваліфікованих ознак притягнення завідомо невинного до кримінальної відповідальності.

Тяжкі або особливо тяжкі наслідки, що можуть настати внаслідок завідомо незаконного затримання, приводу, домашнього арешту або тримання під вартою, можна поділити на матеріальні і нематеріальні. До матеріальних тяжких наслідків належить шкода, яка має особистий (фізичний) характер (самогубство потерпілого, його інвалідність, психічне захворювання, втрата вагітності тощо), чи упущена вигода у великому або особливо великому розмірі. До нематеріальних тяжких наслідків слід віднести порушення основних конституційних прав і свобод значної кількості громадян, тривале тримання під вартою особи тощо.

Отже, завідомо незаконні затримання, приводи, домашні арешти або тримання під вартою повинні не тільки передувати настанню тяжких наслідків за часом, але й мають виступати головними і визначальними умовами з необхідністю тягти настання тяжких наслідків. Що стосується таких ознак (наслідків), як тяжкі наслідки, то під ними слід розуміти: а) замах на самогубство, самогубство, тяжке захворювання, тяжкі тілесні ушкодження, загибель важкохворих близьких, які залишилися без догляду, позбавлення життя такої особи іншими затриманими тощо; б) спричинення потерпілому великої матеріальної шкоди. Склад злочину, закріплений в ч. 3 ст. 371 КК, за ознакою «тяжкі наслідки» $\epsilon$ матеріальним, тобто злочин вважається закінченим з моменту настання таких наслідків.

Під такою кваліфікуючою ознакою, як вчинення злочину з корисливих мотивів, слід розуміти спонукання винного до отримання будь-якої матеріальної вигоди (заволодіти грошима, коштовностями, цінними паперами, майном, одержати майнові права, уникнути матеріальних витрат чи обов'язків або досягти іншої матеріальної вигоди).

Під вчиненням цього злочину в інших особистих інтересах слід розуміти поліпшення показників службової діяльності, помсту, демонстрацію власної значимості, неправильно зрозумілі інтереси, заздрість, прагнення допомогти товаришу, прагнення просунутися кар'єрою, отримати нагороду, чергове звання тощо [9, с. 180-182].

Висновки. Вважаємо, що слід підвищити межі заподіяння шкоди й врахувати заподіяння особливо тяжкої шкоди. Необхідність урахування в диспозиції статті настання таких наслідків викликана низкою негативних тенденцій, які простежуються сьогодні в підрозділах правоохоронних органів, та дозволить розширити настання й інших негативних наслідків злочину, які на практиці не враховуються (розірвання контрактів, банкрутство, настання фінансової неспроможності тощо необхідно вважати тяжкими наслідками, а заподіяння тяжких тілесних ушкоджень, що спричинили смерть потерпілого, доведення до самогубства, заподіяння смерті тощо - особливо тяжкими наслідками). Отже, додаткова кваліфікація за сукупністю злочинів $\epsilon$ недоцільною [1, с. $140-151 ; 3 ; 10$, с. 165-182]. 


\section{Література}

1. Воронцов А.В. Кримінальна відповідальність за вчинення злочинів проти правосуддя, які вчинюються службовими особами органів дізнання та досудового слідства : дис. ...канд. юрид. наук : 12.00.08 «Кримінальне право та кримінологія; кримінально-виконавче право». Одеса : МГУ, 2011. 269 с.

2. Гуторова Н.А. Уголовное право Украины: особенная часть : конспект лекций. Харьков : Одиссей, 2003. 320 с.

3. Ігнатов О.М. Насильницькі злочини, що вчинюються працівниками органів внутрішніх справ України: кримінологічна характеристика, детермінація та попередження : монографія. Харків:ТОВ «Вид-во «ФорматПлюс», 2008.296с.

4. Кримінальний кодекс України : Закон України від 05. 04. 2001 р. № 5460-VI (5460-17) із змін., внес. згідно із законами України та Рішеннями Конституційного Суду, станом на 27. 06. 2019 p. URL: http: / /zakon.rada.gov.ua.

5. Кримінальний процесуальний кодекс України : Закон України від 19.10.2012 р. № 5076-VI із змін., внес. згідно із законами України та Рішеннями Конституційного Суду, станом на 10. 11. 2018 p. URL: http://zakon.rada.gov.ua.

6. Про внесення змін до деяких законодавчих актів України у зв'язку з прийняттям Кримінального процесуального кодексу України : Закон України. Харків : Одіссей, 2012. 360 c.

Протидія злочинності: проблеми практики та науково-методичне забезпечення

7. Науково-практичний коментар до Кримінального кодексу України. 5-те вид. переробл. та доповн. / за ред. М.І. Мельника, М.І. Хавронюка. Київ : Юридична думка, 2008. 1216 c.

8. Про Національну поліцію : Закон України від 02.06.2015 р. № 580-VIII із змін., внес. згідно із законами України та Рішеннями Конституційного Суду, станом на 25.11.2018 p. URL: http: / /zakon.rada.gov.ua.

9. Слуцька Т.І. Кримінальна відповідальність за злочини, вчинені у сфері службової діяльності : навч. посіб. Київ : КНТ, 2007. 168 с.

10. Шнипко О.А. Кримінально-правове дослідження злочину «завідомо незаконні затримання, привід, домашній арешт або тримання під вартою» (ст. 371 КК України) : дис. ... канд. юрид. наук : 12.00 .08 «Кримінальне право та кримінологія; кримінально-виконавче право». Київ : ВН3 «Національна академія управління», 2017. 282 с.

Воронцов А. В., кандидат юридичних наук, доцент, доцент кафедри кримінального права та кримінології факультету підготовки фахівців для органів досудового розслідування одеського державного університету внутрішніх справ 